\title{
"Se a história é nossa, deixa que nóis escreve": os rappers como historiadores
}

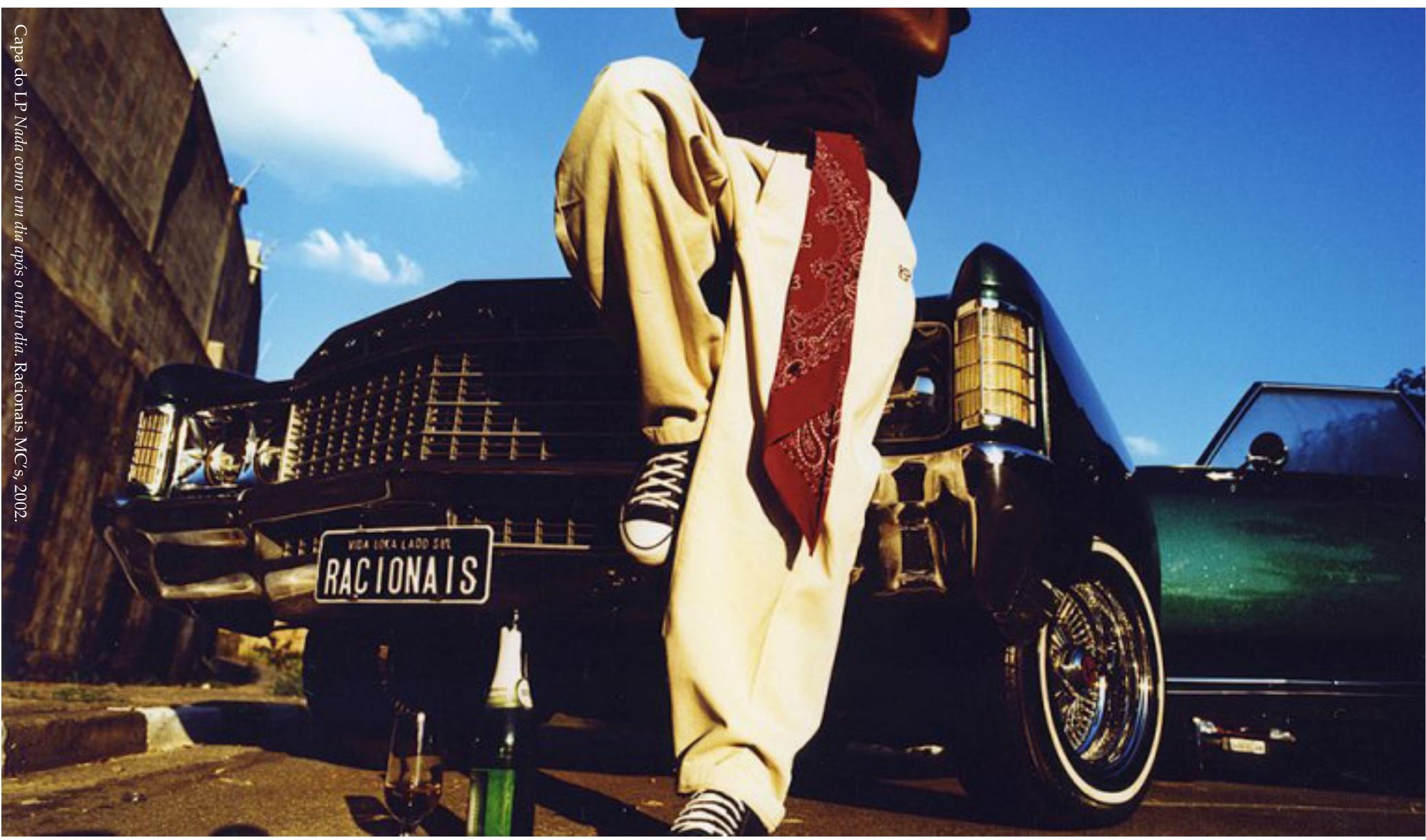

\section{Roberto Camargos}

Doutor em História pela Universidade Federal de Uberlândia (UFU). Professor do Instituto de Educação, Letras, Artes, Ciências Humanas e Sociais (IELACHS) da Universidade Federal do Triângulo Mineiro (UFTM). Autor do livro Rap e política: percepções da vida social brasileira. São Paulo: Boitempo, 2015. robertoxcamargos@gmail.com 
${ }^{1}$ TADDEO, Luiz Eduardo. A guerra não declarada na visão de um favelado. São Paulo: 2013 (independente).

2 "Diário de um detento". Racionais MC's. CD Ao vivo em Uberlândia, s./d. (não oficial).

${ }^{3}$ Apesar do crescente número de trabalhos sobre a história do tempo presente, seus métodos e conceitos básicos ainda permanecem um tanto quanto fluidos. Jean Lacouture considera que ela é marcada pela proximidade temporal dos temas estudados e o contato mais ou menos direto que o pesquisador pode manter com essas temáticas. Para Robert Frank, essa especialidade tem por particularidade a tentativa de explorar os fundamentos de determinadas questões e acontecimentos, seus processos e as muitas relações de força que configuram limites e pressões nos seus desdobramentos, afastando-se de outras perspectivas e abordagens de assuntos recentes, como alguns que são frequentes no meio jornalístico. Ver LACOUTURE, Jean. A história imediata. In: LE GOFF, Jacques. A história nova. São Paulo: Martins Fontes, 1990, FRANK, Robert. Écrire l'histoire du temps présent. Paris: Institut d'Histoire du Temps Présent, 1993, e HOBSBAWM, Eric. O que a história tem a dizer-nos sobre a sociedade contemporânea? In: Sobre história. São Paulo: Companhia das Letras, 1998.

${ }^{4}$ Neste artigo privilegiei uma abordagem por intermédio da música, mas é possível atacar a questão também por outros aspectos, como o literário. Alguns rappers que aparecem citados aqui produziram, entre outras, as seguintes obras: GHÓEZ, Preto. A sociedade do código de barras. São Paulo: Estação Hip Hop, 2008, TADDEO, Carlos Eduardo, op. cit., SOARES, Luiz Eduardo, ATHAYDE, Celso e BILL, MV. Cabeça de porco. Rio de Janeiro: Objetiva, 2005, ATHAYDE, Celso e BILL, MV. Falção: meninos do tráfico. Rio de Janeiro: Objetiva, 2010, SILVA, Reginaldo Ferreira da (Ferréz). Capão pecado. São Paulo: Labortexto, 2000, idem, Manual prático do ódio. Rio de Janeiro: Objetiva, 2003, idem, Ninguém é inocente em São Paulo. Rio de Janeiro: Objetiva, 2006, e INQUÉRITO, Renan. Poucas palavras. Campinas: 2013 (independente).

\section{"Se a história é nossa, deixa que nóis escreve": os rappers como historiadores}

"If history is ours, let us write it": rappers as historians

Roberto Camargos

\section{RESUMEN}

Neste artigo, analiso como alguns rappers se colocaram na condição de "historiadores" do tempo presente, oferecendo a seu público narrativas que se propõem a dar conta de explicar o mundo contemporâneo, esmiuçar suas contradições e revelar verdades supostamente ausentes em outros relatos/histórias da vida social (segundo eles, entre as versões da história que criticam estão as midiáticas e até mesmo as que figuram nos livros de história). Como resultado, os rappers acabam criando também novos marcos e seus próprios heróis, dimensão que exploro ao tomar como exemplo bem-sucedido o caso de Sabotage, uma legenda do rap.

palabras Clave: música rap; usos do passado; memórias.

\begin{abstract}
In this article I address how a few rappers have seen themselves as "historians" of present time who offer their public narratives meant to explain the contemporary world, to dissect its contradictions and to reveal truths supposedly not found in other narratives (among the versions of history they criticize are those offered by the media and even history books). As a result, rappers end up also creating new milestones and their own heroes, dimension that I explore when taking as example successful case of rapper Sabotage.
\end{abstract}

KEYWORDS: rap music; uses of the past; memories.

\begin{abstract}
Assevero, sem medo de errar, que hoje sou um autodidata em morticínio. É bem verdade que, do alto da minha $5^{\underline{a}}$ série não concluída do ensino público fundamental, nunca publiquei teses ou dissertações, porém sou mais capacitado para escrever sobre a atmosfera agonizante abaixo da linha da pobreza do que qualquer sociólogo playboy...
\end{abstract}

Luiz Eduardo Taddeo ${ }^{1}$

Em uma das apresentações que o Racionais MC's realizou em Uberlândia, Mano Brown, antes de começar a cantar os dramas de "Diário de um detento", avisou ao público, num desabafo raivoso e catártico, que "a história do Brasil vai ser escrita com sangue, com tinta vermelha de negro, favelado, sofredor, pobre da periferia".$^{2}$ A música que veio em seguida, recebida com calorosos aplausos e gritos, mostrou quem tinha assumido essa tarefa de contar tal "história do Brasil". Afinal, a composição dissecava um triste acontecimento do passado recente (o massacre do Carandiru) 
articulando memórias, canto/fala e musicalidade, para sustentar - com base no caso dos presidiários - a opinião de quem via irresponsabilidade e autoritarismo nas ações do governo do estado de São Paulo.

Isso se afina com o que Brown e outros rappers e grupos vêm fazendo por meio de suas canções: estabelecem um diálogo com o passado e escrevem, a seu modo, uma história do tempo presente ${ }^{3}$ em que a dureza de algumas experiências - segundo os rappers, negligenciadas nos relatos oficiais - é a principal matéria-prima. ${ }^{4} \mathrm{Gog}$, por exemplo, adverte que "caminhamos pelo Brasil, assim, de uma forma simples, mas com um texto forte, $[. .$.$] tentando passar a nossa verdade". { }^{5}$ Thaíde, na mesma linha, explica que "não sou dono da verdade, mas tenho minha história". ${ }^{6}$

Essa visão nos conduz a algumas pontas de um complexo emaranhado de fios que tecem a vida social e que estão presentes na produção da maioria dos rappers: o próprio tempo, o seu povo e os lugares de vivências ou de origem. No seu entendimento, a tarefa que assumiram como narradores de uma época era inadiável, pois alimentam a pretensão de serem as pessoas mais capacitadas para tanto. E assinalam que "eles [sujeitos geralmente da classe média, como jornalistas, cineastas, acadêmicos] contam nossa história de maneira equivocada". ${ }^{7}$ É por isso que os grupos ligados ao rap trouxeram para o centro de sua arte temas como a experiência racista na sociedade, a valorização da juventude negra, as décadas de sofrimento ao qual o povo pobre do país foi submetido, a violência urbana e muitas outras faces da "brava gente brasileira". ${ }^{8}$ São essas características, próprias do diálogo dos brasileiros com os aspectos "universais" da linguagem rap, que levam Teresa Fradique, uma estudiosa dos rappers portugueses, a destacar que no "discurso [...] é visível a consciência de se estar a 'fazer história', a 'inovar' e a pesquisar novos caminhos, ou seja, a criar novos espaços geográficos, sociais e simbólicos na cidade e nos seus arredores". ${ }^{9}$

\section{Música popular e história}

Essas questões me transportam para um artigo sobre a música popular brasileira escrito pela historiadora Heloisa Starling..$^{10}$ Nele, a autora pega carona em "Qualquer canção"11, composição de Chico Buarque, para pôr em discussão o fato de as músicas constituírem uma forma de produção de conhecimento (mais ou menos enviesado, como qualquer outro) sobre o que se experimenta, seja na concretude do vivido ou na subjetividade das pessoas. A autora, que valoriza o papel que o cancioneiro nacional pode assumir na construção de leituras para a realidade social, ressalta que não se deve esperar do artista uma representação fiel do mundo ou mesmo a competência de agir diretamente sobre ele - algo que, evidentemente, vale para qualquer tipo de narrativa ou de profissional. Entretanto, apesar de sua ressalva, que na verdade visa salientar que há nas representações em qualquer relação com a "coisa em si"12, ela afirma que as canções "podem, muitas vezes, reconciliar cada um de nós com seu próprio passado, narrando-o a nós mesmos e a outros" ${ }^{13}$

Essa concepção que converte, ou melhor, reconhece, a produção musical em fonte de saberes sobre a experiência histórica é, de certo modo, recorrente entre os pesquisadores da canção popular no Brasil. Marcos Napolitano, por exemplo, comenta que "entre nós, brasileiros, a canção [...] tem sido termômetro, caleidoscópio e espelho não só das mudanças sociais, mas sobretudo de nossas sociabilidades e sensibilidades coletivas
${ }^{5}$ Gog. Série Produção Cultural no Brasil, maio 2010.

${ }^{6}$ ALVES, César. Pergunte a quem conhece: Thaíde. São Paulo: Labortexto, 2004, p. 17.

${ }^{7}$ Entrevista com MV Bill. O Globo, 8 set. 2002.

8 "Imagem brasileira". Consciência Humana. LP Enchergue [sic] seus próprios erros. São Paulo: M. A. Records, 1993.

${ }^{9}$ FRADIQUE, Teresa. Nas margens... do rio: retóricas e performances do rap em Portugal. VELHO, Gilberto (org.). Antropologia urbana: cultura e sociedade no Brasil e em Portugal. Rio de Janeiro: Zahar, 1999, p. 125.

${ }^{10}$ STARLING, Heloisa Maria Murgel. Música popular brasileira: outras conversas sobre os jeitos do Brasil. In: BOTELLHO, André e SCHWARCZ, Lilia Moritz (orgs.). Agenda brasileira: temas de uma sociedade em mudança. São Paulo: Companhia das Letras, 2011.

11 "Qualquer canção" (Chico Buarque). Chico Buarque. LP Vida. Reio de Janeiro: Polygram/Philips, 1980.

${ }^{12}$ Ginzburg, ao refletir sobre as relações entre o real e sua representação, argumenta que é preciso estar atento para o opaco, as distorções e imprecisões das práticas de representação, o que, no entanto, não implica a negação da existência de algo concreto. Sua perspectiva é particularmente clara ao dialogar com Renato Serra: "Serra sabia bem que todas essas narrações, independente do seu caráter mais ou menos direto, têm sempre uma relação altamente problemática com a realidade. Mas a realidade ('a coisa em si') existe." Ver GINZBURG, Carlo. O extermínio de judeus e o princípio da realidade. In: MALERBA, Jurandir (org.). A história escrita: teoria e história da historiografia. São Paulo: Contexto, 2006, p. 226.

${ }^{13}$ STARLING, Heloisa Maria Murgel, op. cit., p. 366. 
${ }^{14}$ NAPOLITANO, Marcos. Pretexto, texto e contexto na análise da canção. In: SILVA, Francisco Carlos T. (org.). História e imagem. Rio de Janeiro: UFRJ/Proin-Capes, 1998, p. 199.

${ }^{15}$ MORAES, José Geraldo Vinci de. História e música: canção popular e conhecimento histórico. Revista Brasileira de História, v. 20, n. 39, São Paulo, 2000, p. 203.

16 "Contra tempo". Consciência Ativa. CD Na mira do sistema. Campo Mourão: s./d. (independente).

${ }^{17}$ STARLING, Heloisa Maria Murgel, op. cit., p. 366.

${ }^{18}$ MELLO, Caio B. A poesia envenenada dos Racionais MC's: superávit de negatividade e fim de linha sistêmico, s. ref./ impresso, 2000, p. 7.

${ }^{19} \mathrm{Idem}$. mais profundas".$^{14}$ José Geraldo Vinci de Moraes, por sua vez, frisa que a música popular é portadora de elementos passíveis de ajudar a "desvendar processos pouco conhecidos e raramente levantados pela historiografia", em especial no que concerne aos "setores subalternos e populares". ${ }^{15}$

Os posicionamentos desses estudiosos se assentam na constatação de que as canções, em muitos casos, são produzidas a partir de informações relativas à vida social. No que se refere ao rap, é bom dizer, os compositores quase sempre reivindicam uma relação de proximidade com o vivido, como fazem os MCs do Consciência Ativa, que ponderam que "o meu rap não é perfeito mas fala a realidade" ${ }^{16}$ Isso conferiu a elas o status de legítimas produtoras de um pensamento sobre o Brasil. Por obra e graça de sua poética, o cancioneiro abre "trilhas no emaranhado das coisas humanas, opina sobre elas, discute quanto valem, dá caráter público àquilo cujo conhecimento estaria, num primeiro momento, fechado no coração do homem, e expõe de modo transparente a verdade íntima dos sentimentos humanos". ${ }^{17}$

Ainda na esteira de Starling, convém sublinhar que isso se deve, em parte, a que no Brasil a força da palavra oral é historicamente maior que o hábito da palavra escrita. Em decorrência disso, reflexões e memórias encontraram morada e ganharam contornos e elaborações bastante significativas nas práticas orais. Essa herança, que remonta à época colonial e ao fluxo de africanos para o país, sedimentou um solo fértil para acolher o rap tempos depois. Por outro lado, características sociais como a constância e a magnitude do analfabetismo e a existência de amplos setores da população com acesso precário à educação ou semiescolarizados contribuíram para que os traços de oralidade fossem dominantes em determinad as práticas culturais. A oralidade, encarada como um valor cultural importante, foi defendida e "preservada" a despeito do avanço do letramento e da ampliação dos níveis de escolaridade. Daí que experiências artísticas predominantemente orais favoreceram a emergência de narrativas que criaram imagens do mundo, construíram leituras para processos históricos, inventaram perspectivas de análise, promoveram a luta para legitimar e/ou deslegitimar interpretações.

A relevância de um ambiente oral é particularmente expressiva no caso do gênero aqui enfocado, tanto que, para Caio Mello, "a transposição do rap para a forma escrita mereceria no mínimo uma explicação que justificasse esse, por assim dizer, quase desrespeito". ${ }^{18}$ Tal observação parte, sem dúvida, do entendimento de que o texto não dá conta de compreender ou traduzir totalmente a música, pois a complexidade dos sons, efeitos, intensidades e volumes por vezes não cabem nos limites da palavra escrita. Ao analisar o CD Sobrevivendo no inferno, do Racionais $\mathrm{MC}^{\prime}$ s, ele escreve:

A exclusão das letras do encarte do $C D$, antes de ser um descuido ou alguma impossibilidade qualquer, pode ser entendida como mais uma forma de resistência, na medida em que se dificulta o deslocamento do discurso desde seu lugar e contexto originais até outros que poderiam alterar-lhe potencialmente o sentido, fazendo com que seus tiros acertassem outros alvos ou não acertassem nenhum. [...] os sentidos mais profundos do discurso, da narrativa [...] só podem ser compreendidos quando se ouve o $C D$, inteiramente, rap por rap [...] O que há de intraduzível e indescritível na empostação da voz em cada palavra proferida pelo rapper é muito, sobretudo como elemento fundamental para a constituição dos sentidos. ${ }^{19}$

A voz e a fala, concatenados com elementos sonoros e musicais di- 
versos, constroem um campo de reflexões no âmbito da produção musical. É assim, fazendo uso de suas canções, que muitos compositores ambicionam informar aos seus ouvintes o que foi e o que é este país. ${ }^{20}$ Mas há os que se propõem ir além. Sintonizados com o pensamento de que a música produz conhecimento e transmite saberes, ambicionam prover à sociedade concepções de que ela foi privada, investindo no que foi esquecido, escondido, esclipsado ou anulado em outros discursos sobre o social..$^{21}$ É daí que surgem músicas com posicionamentos repletos de sentimentos que vão da desconfiança ao ódio em relação a história oficial e/ou às falas hegemônicas tão ao gosto das classes dominantes. Em nada satisfeitos com essas narrativas - pelas quais "o burguês discrimina/ fala mal de mim, de você, da sua mina" e "apoia a chacina [do povo negro e pobre]/ desmerece o artista, o ativista" 22 - , sugerem novos enredos que garantem aos rappers algum protagonismo no processo: "e por isso eu vou/ escrevendo minha própria história/ entre pedras e espinhos/ que no caminho sempre rola". ${ }^{23}$ É, portanto, de lá, do chão histórico de uma experiência pessoal ou socialmente circunscrita, que despontam juízos que se ampliam e se arvoram em ponderações mais gerais, válidas para a sociedade como um todo. ${ }^{24}$ Dessa maneira, como

veículo de trocas, durante todo o século XX, a canção popular cortou transversalmente nossa pólis, independente de gênero e estilo, providenciando um estoque de referências para a vida pública brasileira passível de reconhecimento por uma audiência ampla, de nível social ou cultural diversificado. De algum modo, através dela, ou por seu intermédio, circularam ideias e transitaram publicamente pontos de vista num processo de troca, negociação e confronto de opiniões - que, decantadas do particularismo arbitrário ou indiossincrático, puderam vir a transformar-se em opinião pública. ${ }^{25}$

Os sujeitos envolvidos nesse processo de reconfiguração das experiências geralmente situadas em um passado imediato ou no seu presente mergulharam, então, nas questões da coletividade, problematizando, com frequência, a formação e a reprodução das relações sociais. Os rappers cumpriram de forma magistral esse pape ${ }^{26}$, polemizando e criticando diretamente a situação do país, concebido por eles como solo de terríveis desigualdades.

Detalhe intrigante é que para eles contam pouco os questionamentos acerca das intricadas relações entre noções de verdade, realidade e ficção ${ }^{27}$, de resto muito comuns em outros tipos de narrativa sobre o passado, como nos livros ficcionais e nos filmes. Isso, em larga medida, guarda íntima relação com a ideia amplamente disseminada de uma associação inescapável entre rap e realidade/verdade, como reconheceu Mano Brown em conversa com os integrantes do Negredo, Ferréz e outros manos da Zona Sul de São Paulo: "essa cultura de cantar a realidade [...] o rap é a música de realidade, não foi [essa] a coluna que segurou toda essa estrutura de rap de todo mundo aqui? Seus livros, minhas músicas, o documentário?" 28 Nesses casos, tomando emprestadas palavras de Chartier e retirando-as de seu contexto original - uma reflexão sobre a instituição histórica -, "o real é ao mesmo tempo o objeto e o fiador do discurso". ${ }^{29}$

De fato, atribui-se aos raps um caráter de verdade - não no sentido das narrativas serem o reflexo do real, mas de serem opostas à ficção, à fantasia - que procura convencer o ouvinte valendo-se de estratégias de
${ }^{20}$ Eduardo, do Facção Central, considera que parcela importante do seu trabalho artístico consiste em fazer "o possível para conscientizar o nosso povo". Duck Jay, não fica atrás: "a proposta [do seu trabalho] é [...] sempre a conscientização". Entrevista com Facção Central. Rap Nacional, nov. 2006, e entrevista com Duck Jay. Rap Nacional, jan. 2004.

${ }^{21}$ Isso é especialmente evidente em "Terrorista". Realidade Cruel. CD Mais cruel do que nunca. Hortolândia: Face da Morte, 2002, em que o protagonista da ação narrada pelos rappers interpela (pela oralidade) seu interlocutor (cultor da palavra escrita): "satisfação, jornalista, aqui é a matéria que você deleta/ [...]/toda informação distorcida tem o seu preço/ e é justo que eu cobre caro, nada extraordinário".

22 "É o terror". GOG. CD CPI da favela. Brasília: 2002 (independente).

23 "Lutar é preciso". Gíria Vermelha. CD A hora do revide, 2008. Uma curiosidade pertinente à discussão: dois dos integrantes do Gíria Vermelha, Hertz e Verck, são graduados em História e mestres em Educação.

${ }^{24}$ Um exercício muito próximo, aliás, do que realiza a microhistória. Sobre o assunto, ver LIMA, Henrique Espada. A micro-história italiana: escala, indícios e singularidades. Rio de Janeiro: Civilização Brasileira, 2006.

25 STARLING, Heloisa Maria Murgel, op. cit., p. 372.

${ }^{26} \mathrm{O}$ que não significa ignorar simplificações e maniqueísmos em suas representações do real, conforme já apontei em CAMARGOS, Roberto. Rap e política: percepções da vida social brasileira. São Paulo: Boitempo, 2015, esp. no capítulo Representações, experiências, verdades.

${ }^{27}$ Sobre o assunto, ver, entre outros, GINZBURG, Carlo. O fio e os rastros: verdadeiro, falso, fictício. São Paulo: Companhia das Letras, 2007.

${ }^{28} 100 \%$ favela. Brasil: Atração Fonográfica, 2006. 1 DVD (son., color.).

${ }^{29}$ CHARTIER, Roger. A história ou a leitura do tempo. Belo Horizonte: Autêntica, 2009, p. 25. 
${ }^{30}$ Essa ideia é tão recorrente e forte no meio que um grupo de Goiânia adotou como nome Testemunha Ocular. Ouvir Testemunha Ocular. CD Frutos da rua. Goiânia: Two Beer or Not Two Beer, 2003. O título do disco fornece pistas do que os rappers testemunham com os próprios olhos: o cotidiano das ruas.

${ }^{31}$ Ouvir "Três corações". Gog. CD Tarja preta. Brasília: Só Balanço, 2003, "O bagulho é doido". MV Bill. CD O bagulho é doido. Rio de Janeiro: Chapa Preta, 2006, "Mágico de Oz". Racionais MC's. LP Sobrevivendo no inferno, op. cit., "Conversando com os mortos". Facção Central. CD Direto do campo de extermínio. Hortolândia: Face da Morte, 2003.

32 Ouvir "Interlúdio". Consciência X Atual. CD A ressureição. Brasília: Discovery, 1999, “Pt. 2", "Hey boy" ou "Mulheres vulgares". Racionais MC's. Col. Racionais MC's. São Paulo: Zimbabwe, 1994.

${ }^{33}$ Ouvir "Na zona sul". Sabotage. CD Rap é compromisso. São Paulo: Cosa Nostra, 1999, em que a temporalidade e o espaço da narrativa, virada dos séculos XX/XXI e a zona sul da capital paulista, são minuciosamente descritos e construídos como palco da história.

${ }^{34}$ Ouvir "Profissão perigo". Rodrigo Ogi. CD Crônicas da cidade cinza. São Paulo: 2011 (independente), composição cujo sentido e clima são totalmente dependentes dos sons roubados do cotidiano e das ruas de uma grande cidade.

${ }^{35}$ CERTEAU, Michel. A escrita da história. Rio de Janeiro: Forense Universitária, 1982, p. 111.

${ }^{36}$ Carlo Ginzburg, por exemplo, já demonstrou como o mesmo procedimento é fundamental e muito presente no trabalho dos historiadores, que sempre buscam um "efeito de verdade" para suas narrativas. Ver GINZBURG, Carlo. O fio e os rastros, op. cit.

${ }^{37}$ Cartão-postal Bomba. Direção: Marcius Barbiere, Angel Duarte e Ariel Feitosa. Brasil: Só Balanço, 2009. 1 DVD (son., color.).

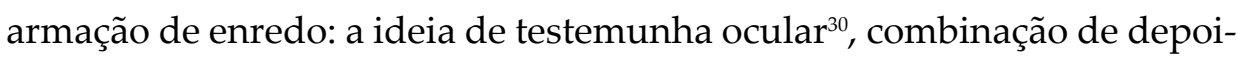
mentos orais inseridos na trama como citação de um documento ${ }^{31}$, promoção de diálogos entre personagens ${ }^{32}$, delimitação espacial e temporal ${ }^{33}$, incorporação de sons do cotidiano ${ }^{34}$, criação uma atmosfera/clima musical que potencializa e dramatiza o relato feito. Com certa semelhança com o trabalho do historiador, o rapper tenta produzir credibilidade e até "extrai da citação uma verossimilhança do relato e uma validade do saber" ${ }^{35}$ Cabem, claro, alguns questionamentos. O compromisso declarado com a "verdade" garante alguma "exatidão" a essas narrativas? A mescla de elementos retirados da experiência - como defendem os rappers - de fato afasta dos raps o espectro da ficção?

As relações mais ou menos diretas com a realidade social não impedem que parte das composições dos rappers sejam consideradas como narrativas "históricas", como portadoras de uma consciência histórica. Não há como negar. Nas suas obras estão inscritas as transformações sociais, os arranjos urbanos, as relações das pessoas com os espaços, os sentimentos, as lutas cotidianas, a desigualdade no acesso aos serviços públicos, a opressão das normas sociais, a crítica, a adesão seletiva ou negação da ordem vigente e outras dimensões da luta pela sobrevivência. Muitas delas, ao tratarem desses temas, partilham concepções políticas e éticas com a historiografia de sua época, mesmo obedecendo a regras e procedimentos próprios. Complementarmente, tal como uma parcela da historiografia de seu tempo, na narrativa dos rappers ocorre uma inversão do olhar que resulta em uma história vista de baixo, contando ao público em geral o que foram as últimas décadas pelo ponto de vista de quem se coloca ao nível das classes/personagens populares. Carregando mais em determinadas cores e menos em outras, os músicos rememoram situações/ fatos/eventos, reconstroem parcialmente épocas e lugares, conferem significados a experiências múltiplas. É isso que se percebe no contato com as músicas, um trabalho de memória que empresta à história narrada pelos rappers inequívocos contornos de verossimilhança. ${ }^{36}$ Assim, vale a pena ouvir com atenção o mundo pensado/produzido por essas composições, um tipo de história que chega a ser complexa a ponto de termos de aprender a interpretá-la. Os compositores, quase sempre, mostram-se conscientes do que realizam ao contarem/cantarem narrativas que enfocam um passado recente, como explica Gog:

\begin{abstract}
São momentos diversos. São acontecimentos em tempos diferentes, músicas diferentes. Mas olha só, "Momento seguinte", "Periferia segue sangrando", "Mais uma história" e "Quando o pai se vai", quando você pega cada um deles, cada uma dessas criações e você monta, você: "Caramba! Olha só que quebra-cabeça! Que louco, um quebra-cabeça social. [...]

Só pra você ver, "Assassinos sociais", "Fogo no pavio", "Eu e Lenine - a ponte", tudo isso, se você perceber, aconteceu comigo, mas aconteceu com você também e você consegue entender o que eu falo..$^{37}$
\end{abstract}

Essas explicações de Gog abrem uma via de entendimento para o seu processo criativo, para o modo como ele pensa o rap e o papel que atribui à sua poética. Nas entrelinhas, parece indicar que por intermédio do rap ele opera como um "historiador", querendo entender e escrever uma história imediata. A proposta é desafiadora; afinal, aceitar que músicas do universo rap possam transmitir algum conteúdo sério sobre o passado foge, ao menos 
em tese, do que aprendemos sobre o que é essa disciplina/campo do saber.

Convém esclarecer: a relação que os rappers estabelecem com os aspectos da vida social, com o passado, não é da ordem do mero inventário, da coleção de experiências que passam a compor os seus relatos. O que eles fazem é expressão de uma prática ativa que envolve seletividade, escolhas, recortes, pesquisa e a construção de leituras próprias, sentidos e significados afinados com valores, vivências e expectativas específicas de um grupo social. Exemplar, a esse respeito, é o que diz Eduardo em uma das muitas entrevistas que concedeu a Mandrake e à equipe do portal de notícias Rap Nacional:

os assuntos que serão abordados vềm da sua percepção diante de tudo que você viu, penso muito na maneira em que eu vou colocar cada palavra na música, é um trabalho minucioso, é um castelo de cartas, se uma estiver errada, todas cairão [...] sua missão não é apenas noticiar, senão eu seria âncora de jornal, antes de ser um relato social se trata de uma música, esse relato sairá do seu cérebro em forma bruta como notícia e denúncia e terá que ser lapidado dia após dia para que se transforme no diamante, em música, num rap contundente de atitude. ${ }^{38}$

O rap contundente, de atitude, é o que carrega uma visão de mundo, portador de uma interpretação que dê sentido para o que foi ou para o que é vivido - ou, pensando com Benjamin, que seja capaz de transformar vivências em experiências comunicáveis. ${ }^{39}$ Nessa concepção, é a construção de significados que difere as narrativas criadas pelos rappers de outras que por vezes abordam os mesmos temas e acontecimentos. É o caso, mais uma vez, de escutar com atenção o que Gog tem a dizer. Ao comentar a sua música "Sonho real", que dialoga com algumas experiências da luta pela terra no Brasil e alude à experiência de alguns lutadores (citados nominalmente no início da faixa) que inspiraram as suas reflexões, ele sugere que a perspectiva do rap é diferente e até oposta à apresentada em outros discursos, inclusive os jornalísticos e acadêmicos. Para Gog,

o rap é o jornal do povo, ele fala a linguagem do povo, o que o povo quer ouvir, mas ele dá uma cara de qualidade nisso [...] o hip hop, como é que faria? Ele poderia até tirar uma foto dele, mas diria assim: seu Zé, trabalhador, várias derrotas que nunca o fizeram curvar, ele não parou de caminhar, ele não parou de respirar. Ele ainda tem sangue nas veias. Para mim, ele é mais um rebelde brasileiro. Quer dizer, ele é atração na quebrada, ele não é o cara que é só derrota. Dentro da derrota dele tem várias vitórias. ${ }^{40}$

O rap, aí, não é só produtor de uma leitura sobre a história do tempo presente. Ele opera uma série de valores compromissados com os de baixo, com as classes populares, e dá vazão a narrativas orientadas e sintonizadas com os desejos, pensamentos e angústias que se acredita serem as existentes entre esses sujeitos. ${ }^{41}$ Os rappers, que segundo o hip hopper Marcelino Back Spin, estão "preocupados com a informação" ${ }^{42}$, têm como uma de suas funções autodeclaradas oferecer aos ouvintes narrativas que ajudem o seu público a pensar a própria história, mas não pelo ponto de vista dos setores dominantes. ${ }^{43}$ Eles compõem boa parte de suas músicas pensando na história porque a vivenciaram ou conhecem quem a vivenciou e por crer que as pessoas não devem esquecer o que aconteceu e, mais que isso, precisam ter clareza sobre questões relativas ao processo histórico e que
${ }^{38}$ Entrevista com Facção Central. Rap Nacional, nov. 2006.

${ }^{39}$ Ver BENJAMIN, Walter. O narrador. In: Magia e técnica, arte e politica: ensaios sobre literatura e história da cultura. 8 . ed. São Paulo: Brasiliense, 2012.

${ }^{40} \mathrm{O}$ hip hop brasileiro assume a paternidade - entrevista com Gog, op. cit., p. 117. Spensy Pimentel. Cultura e Pensamento, n. 3, Brasília, nov. 2007.

${ }^{41}$ Subsiste, ao lado da pretensão de se ater à realidade, uma tentativa de cativar o ouvinte e torná-lo receptivo à consciência prática, moral e histórica que permeia as narrativas dos rappers. Como observa Danielle Brasiliense, "quando um narrador seduz, provoca emoções e prende o leitor pelo que o assunto tem de extraordinário, ele leva suas próprias concepções de mundo, porém com a certeza de que essas também fazem parte da consciência moral do leitor e, com isso, não irá desagradálo." BRASILIENSE, Danielle. As contribuições dos romances policiais do século XIX para as narrativas jornalísticas dos crimes contemporâneos. Revista Ecopós: Comunicação e Gosto, v. 17, n. 3, Rio de Janeiro, 2014, p. 4.

${ }^{42}$ Casa do hip hop abre espaço para a cultura de rua. O Estado de S. Paulo, 14 mar. 2000.

${ }^{43}$ Afinal, "sem rota própria, te levam como folha ao vento/ como no velho ditado/ sem lenço, sem documento/ te dominando com a desinformação". Ouvir "Você é influenciado pela mídia". Bandeira Negra. CD Transformação. Cabo Frio: s./d. (independente). 
${ }^{44}$ Após escutar "Só a capa da gaita". Linha Dura. CD Tchapa e cruz. Cuiabá: 2008 (independente), o ouvinte é como que convidado a pensar e ampliar o seu repertório de informações sobre o tema do crack; ao ouvir "Brasil sem educação". Face da Morte. CD Crime do raciocínio. São Paulo: Sky Blue, 1999, é-lhe possibilitado problematizar e refletir sobre a realidade educacional do país; ao atentar para os dramas cantados em "Castelo triste". Facção Central. CD O espetáculo do circo dos horrores. São Paulo: Facção Central Produções Fonográficas, 2006, percebem-se novos argumentos para embasar posicionamentos críticos sobre a saúde pública. E por aí vai.

${ }^{45}$ Cf. BENJAMIN, Walter. Sobre o conceito de história. In: Magia e técnica, arte e política, op. cit.

46 "O verdadeiro MC". Doctors MC's. CD Pra quem quiser ver. São Paulo: Kaskata, 1994. Guardadas as diferenças de época e de contexto, é cabível lançar uma ponte entre essa postura dos rappers e a dos sambistas dos anos 1930, no Brasil. Ao saírem em defesa do samba, eles, com justo orgulho, proclamavam-se "doutores em samba" e "mestres de escolas de samba". Ver PARANHOS, Adalberto. Os desafinados: sambas e bambas no "Estado Novo". São Paulo: Intermeios/CNPq/ Fapemig, 2015, cap. 2, esp. p. 86 e 87.

47 “O verdadeiro MC", op. cit.

${ }^{48}$ CHARTIER, Roger. A mão do autor e a mente do editor. São Paulo: Editora Unesp, 2014, p. 25 e 26.

${ }^{49}$ GINZBURG, Carlo. Apontar e citar: a verdade da História. Revista de História, n. 2/3, Campinas, 1991, p. 92.

${ }^{50}$ Um quilombola com o poder da palavra. Raiz, out. 2006.

${ }^{51}$ Entrevista com Consciência Humana. Rap Brasil, ano 2, n. 18, 2003.

52 "Sangue B". Consciência Humana, op. cit. afetam as suas vidas. Não interessam, portanto, narrativas que não deem conta de estimular o pensamento e possibilitar a ampliação da visão crítica. ${ }^{44}$

Esse entendimento do ato de narrar acontecimentos/eventos/histórias remete à noção de história de Walter Benjamin, seja pelas pontes entre memória e experiência presentes nas narrações ou na atitude que sugere que é indispensável lembrar e também esquecer (para ficar no relato de Gog citado logo acima, esquecer das derrotas para ver as vitórias dentro do mesmo processo histórico, por exemplo). O trabalho dos rappers escova a história a contrapelo ao não aceitar a história do vencedor, que se impõe como continuidade, como memória e poder estáveis e mais ou menos inalteráveis e tenta jogar para a sombra as memórias de outros grupos sociais. ${ }^{45}$

Memória e experiência emergem, por essa via, como forma de pensamento, pois o movimento de lembrar e esquecer produz imagens de relações possíveis entre passado e presente, não do passado tal como existiu. Essas imagens são formuladas nos trabalhos de memória empreendidos pelos MCs, a despeito de saberem que "não somos formados", porém "somos doutores/ empregamos no rap todos nossos valores". ${ }^{46}$ Importa frisar que o que conta aí não é a exatidão das narrativas, e sim a perspectiva histórica que anima o rap que "critica o governo de um modo anormal/ fala de um povo e da diferença social/ canta, protesta e avisa dando um toque". ${ }^{47}$

Pensar o trabalho artístico sob essa ótica pode causar algum estranhamento; todavia, esse entendimento, de alguma maneira, se afina com reflexões que têm ganhado força entre os profissionais da História. Roger Chartier, por exemplo, adverte que "os historiadores de hoje não possuem mais o monopólio das representações do passado"; basta verificar que as "insurreições da memória e as seduções da ficção proporcionam uma acirrada competição". ${ }^{48}$ Carlo Ginzburg, por outro lado, cita Aristóteles ao tratar da mesma questão: "Heródoto não seria menos historiador se escrevesse em versos, desde que continuasse a reivindicar um mínimo de verdade para suas proposições sobre a realidade" ${ }^{49}$ É óbvio que o trabalho dos rappers no campo do conhecimento e da cultura é diferente do realizado pelos historiadores. Os compositores, evidentemente, compreendem tal diferença, contudo não abrem mão de que as suas representações do passado sejam reconhecidas como fidedignas e verdadeiras. Por isso o rapper Gil Amâncio valoriza conhecimentos produzidos pelos poetas das ruas: "eu ainda sonho com o dia em que os mestres da cultura popular irão ganhar o título de notório saber e ocupar os espaços das universidades brasileiras"..$^{50}$

É justamente essa ideia do rap como produtor de conhecimento, como portador de uma infinidade de saberes sobre a vida social e a "natureza" humana que fez com que um dos integrantes do Consciência Humana, Aplik, pensasse sobre sua atividade como rapper. Ao passar em revista suas experiências como compositor e ouvinte do gênero, ele declarou, em entrevista à Rap Brasil, que, "a partir do momento que começamos a fazer rap, nossa visão sobre nós mesmos mudou" ${ }^{51}$ Essa colocação, principalmente quando conectada a outros aspectos, ressalta a existência de uma consciência histórica entre os rappers que foi proporcionada - ou pelo menos aguçada -, em parte, pela própria prática do rap, apesar de que, em 2003, ele e seu grupo já acreditavam fazer "um som pesado e conscientizado". ${ }^{52}$

Esse tipo de som remonta à tentativa de muitos rappers de tomar parte na construção de relatos sobre o passado e sobre as experiências sociais, notadamente aquelas vivenciadas por trabalhadores pobres, moradores de periferias e favelas, que sofrem os efeitos perversos do racismo. Tal como 
alguns historiadores, em especial os dedicados à história social, é inegável a intenção dos rappers de converter sua prática cultural em uma atividade política, crítica e militante. Eles ambicionam transformações nos modos de ver, pensar e contar o mundo. Nando, do ClãNordestino, não tem dúvida quanto à importância do rap nesse processo e se considera "um afrodescendente escrevendo outros $500^{\prime \prime 5}$ - ou seja, a história não contada e que é a única com que ele e seus semelhantes podem se identificar. Essa ideia é a que embala "Poucas palavras", de Renan, do grupo Inquérito:

[...] Vou dar um salve, pra quem não sabe

O rap tem base, bagui não é fase

Hoje a favela é moda nas tela

Cidade de Deus, Tropa de Elite, novela

Nóis grava disco, lança livro, faz até sarau

Nóis lava a alma, depois põe pra secar no varal

[...]

Só que pros boy ainda só sou mano

Que fala na gíria, de treta e túmulo

[...]

Poucas palavras, tio, vou ser breve

Se a história é nossa, deixa que nóis escreve $[\ldots]^{54}$

Por aí caminha, também, o Gírias Nacionais ao comentar, mesmo que não diretamente, o trabalho desenvolvido pelos rappers:

\section{[...] Discos divertem}

Divulgam

Descobrem

Dilatam

Descrevem

Desenvolvem...

Desfrutando das deliciosas descrições

Dos doutores das dicções $[\ldots]^{55}$

Em meio a todas essas questões, persistem algumas perguntas: como entender essa linguagem?; como os historiadores se posicionam diante das narrativas dos rappers?; o que essas canções acrescentam à nossa compreensão do passado? Tais indagações permeiam este texto, ao longo do qual procuro pontos de diálogo com elas. Por ora, permitam-me uma provocação: os rappers, ou parte deles, podem ser, ou já são, "historiadores"? Ao analisarmos essas músicas que nutrem a pretensão de alcançar a verdade e/ou de narrar o passado, é preciso ir com calma. Não devemos sucumbir à "realidade" das músicas ou equipará-las ao que realizam os historiadores quando fazem História. Elas, por exemplo, não evidenciam os procedimentos de montagem e interpretação dos fatos, ou seja, entre os rappers não prevalece um conjunto de regras que controlem as operações de seu discurso, mesmo que alardeiem um compromisso ético. Nem poderia ser diferente, já que os procedimentos na área do rap são distintos dos que orientam a história escrita. Os rappers, nesse sentido, não são historiadores, mas, sim, artistas para os quais os acontecimentos do passado são relevantes. Porém, relativizando as coisas, "já são (ou podem ser) historiadores, se, com essa palavra nos referirmos a pessoas que confrontam os vestígios do passado

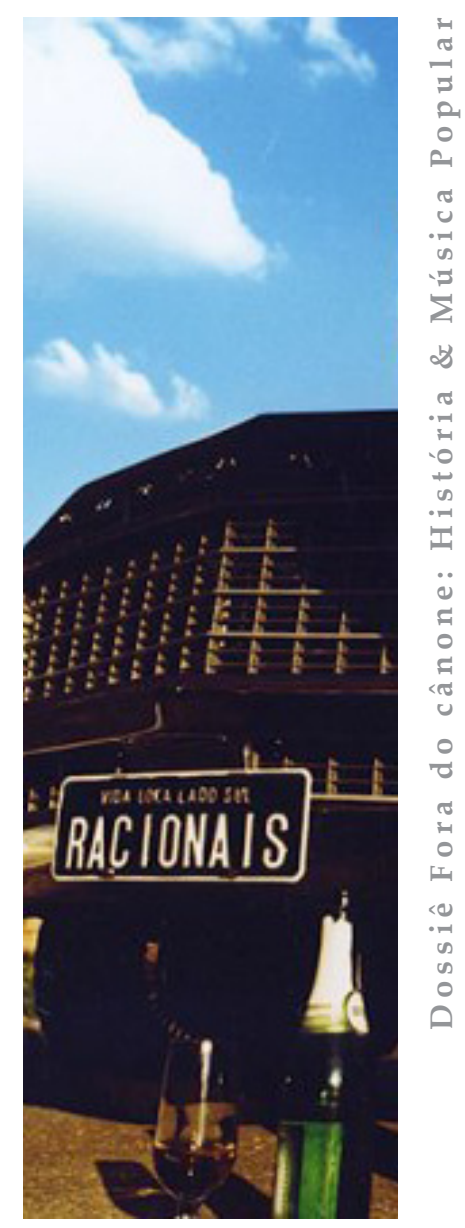

53 "Quantas histórias pra contar". ClãNordestino. CD A peste negra. Hortolândia: Face da Morte, 2003.

54 "Poucas palavras". Inquérito. CD Mudança. Campinas: 2010 (independente).

55 “3D”. Gírias Nacionais. CD Desista de desistir. Taubaté: 2003 (independente). 
${ }^{56}$ ROSENSTONE, Robert A. A história nos filmes, os filmes na história. São Paulo: Paz e Terra, 2010, p. 54

57 "Como vou deixar você" (Paulo Diniz). Paulo Diniz. LP Quero voltar pra Bahia. Rio de Janeiro: Odeon, 1970.

58 "A favela chorou". Sandrão, RZO e Família RZO. São Paulo: 2012 (independente).

59 "Como vou deixar você", op. cit.

${ }^{60}$ Para uma reflexão sobre traumas, memórias e marcas que determinadas experiências produzem, ver GAGNEBIN, Jeane Marie. Lembrar, escrever, esquecer. São Paulo: Editora 34, 2006, esp. o capítulo "O rastro e a cicatriz: metáforas da memória".

61 "A favela chorou", op. cit.

${ }^{62}$ Rapper Sabotage foi atingido por quatro tiros, diz hospital. Folha de S. Paulo [edição on line], 24 jan. 2003.

${ }^{63}$ Morreram. Veja, 29 jan. 2003. Acredita-se que a morte de Sabotage foi provocada por desafetos acumulados nas suas incursões pelo mundo do crime.

${ }^{64}$ Polícia encontra capuz ao lado do corpo do rapper Sabotage. Folha de S. Paulo [edição on line], 24 jan. 2003.

${ }^{65}$ Refiguração, de acordo com Ricoeur, é "a transformação da experiência viva sob o efeito da narração". RICOEUR, Paul apud GAGNEBIN, Jeane Marie, op. cit., p. 172. (rumores, documentos, edifícios, lugares, lendas, histórias orais e escritas) e os usam para contar enredos que fazem sentido para nós no presente" ${ }^{\prime 56}$ Não é isso, afinal, o que eles reivindicam?

\section{Sabotage}

Na canção "A favela chorou" a primeira frase, lançada sobre o beat bem marcado pelo bumbo e pela caixa, vem na forma de sampler, destacando do contexto original algumas palavras contidas numa canção do cantor pernambucano Paulo Diniz: "como vou deixar você?" ${ }^{57}$ Na sequência aparece Sandrão, MC do consagrado RZO - sigla do Rapaziada da Zona Oeste-, em uma performance em tom intimista:
[...] Como deixar a favela,
Como deixar a família,
Como deixar um filho,
Como deixar a fé,
Como deixar a caneta,
Como deixar o sonho,
Como deixar a brisa,
Como deixar a vida? $[\ldots]^{58}$

Esses indícios de um abandono traduzem dor e envolvem uma extensa rede de afetos, relações e emoções. Por isso o sampler volta, dessa vez sonorizando mais quatro palavras: "como vou deixar você... se eu te amo?" ${ }^{99}$ A tensão que brota do jogo armado entre os versos de Paulo Diniz e as ponderações de Sandrão é fruto de feridas abertas, cuja tentativa de cura está no trabalho de memória, na narrativa que elabora simbolicamente o trauma ${ }^{60}$ para superá-lo. As cicatrizes, oriundas de um evento trágico, estão nos versos

\section{[...] Aqui é a dor \\ De um adepto do tio \\ Quem se apresenta}

\section{Sabota, \\ A saudade dói e \\ Aumenta $[\ldots]^{61}$}

Neste ponto o ouvinte percebe que a música é uma homenagem ao rapper Sabotage, que no dia 24 de janeiro de 2003 "foi atingido por disparos por volta das $5 \mathrm{~h} 30$ [...] na zona sul de São Paulo". 62 "Ele foi alvejado por um desconhecido pouco depois de deixar a mulher no trabalho". ${ }^{63} \mathrm{O}$ maestro do Canão, outro modo utilizado pelos rappers para se referirem a Sabotage, "não resistiu e morreu às $11 \mathrm{~h} 25$ " ${ }^{64}$ Todavia, a canção não se presta apenas a homenageá-lo ou extravasar o sentimento de saudade que por certo tomou conta dos compositores (e de muitos outros brasileiros vinculados ou não ao hip hop) que promoveram por meio dela um exercício de refiguração ${ }^{65}$ da perda do amigo Maurinho. Era, igualmente, o ato que estabelecia sua presença na memória dos praticantes, ouvintes e simpatizantes da cultura hip hop. A canção, então, segue na voz de Sandrão com a exteriorização de um sentimento e de um personagem, o Sabotage: 
[...] Mas em todo lugar

Nós sentiremos sua presença

Periferia

Sua cara, sua lembrança é intensa

Um mano humilde, com atitude

Seu potencial ia além

Que mostrou com intensidade

Que "respeito é pra quem tem" $[\ldots]^{66}$

A cada frase, a cada verso, entram em ação os mecanismos da memória. Em um movimento complexo que implica lembranças, esquecimentos, silêncios e falas seletivas, é possível notar a fabricação de um monumento, um ponto de referência que estrutura a memória dos compositores e da coletividade à qual pertencem..$^{67}$ Sob esse aspecto, a música de Sandrão, Celo-X e Família RZO constitui um lugar de memória. ${ }^{68}$ Ajuda na definição do que é comum a esse ou aquele grupo social e, consequentemente, o distingue de outros, alimenta e institui sentimentos variados - como o de pertencimento - e contribui para a elaboração de fronteiras socioculturais. Recorrendo a Michael Pollak, eu diria que a narrativa consolidada por Sandrão e seus companheiros "acentua as funções positivas desempenhadas pela memória comum, a saber, de reforçar a coesão social, não pela coerção, e, sim, pela adesão afetiva do grupo" ${ }^{69}$ Em outras palavras, até mesmo quem não se ligava em Sabotage era induzido a olhá-lo sob outra ótica, a repensar os juízos formados sobre o rapper.

Nessa composição age-se como no caso das testemunhas oculares. Ainda no rastro das reflexões de Pollak, acrescente-se que essas testemunhas "sabem que vão desaparecer [e] querem inscrever suas lembranças contra o esquecimento"..$^{70}$ Há nesse processo inclusive uma função atribuída ao não dito - marcado "pela angústia de não encontrar uma escuta, de ser punido por aquilo que diz ou, ao menos, de se expor a mal-entendidos" ${ }^{\prime 71}-$, algo importante na monumentalização das memórias que se quer instituir na história. Em função disso, caem numa região de sombra aspectos da vida de Mauro que, quando morto, só são recuperados para (e se cumprirem o papel de) reafirmar a história de superação do personagem Sabotage, em sua luta para dar a volta por cima em uma vida dura que prometia condenálo à invisibilidade pública. É o que se verifica quanto ao seu envolvimento com o mundo do crime e com o tráfico de drogas. ${ }^{72}$ Nada demais, já que as narrativas - que lembram, registram, excluem, recalcam, destacam - são resultados de um trabalho de organização. Em se tratando de Sabotage, o que se quer perpetuar não é o Mauro que viveu em uma favela da zona sul de São Paulo e se meteu com expedientes condenáveis, mas o papel positivo cumprido por aquele que "iluminou mentes confusas/ em várias partes da cidade/ só cultivava os amigos/ aos milhões, sem falsidade"73:

\author{
[...] Todos aqui sabem que Sabota é mano eterno \\ E o amor que tu plantou, nego \\ É fonte no deserto \\ Seja no samba, no rap, no reggae \\ Todos têm saudades \\ [...] \\ Vive em ondas sonoras \\ Pelo coração da gente
}

66 "A favela chorou", op. cit.

${ }^{67}$ Sobre memória coletiva, ver HALBWACHS, Maurice. A memória coletiva. São Paulo: Vértice, 1990.

${ }^{68}$ Ver, sobre o assunto, NORA, Pierre. Entre memória e história: a problemática dos lugares. Projeto História, n. 10, São Paulo, dez. 1993.

${ }^{69}$ POLLAK, Michael. Memória, esquecimento, silêncio. Estudos Históricos, v. 2, n. 3, Rio de Janeiro, 1989 , p. 3.

${ }^{70}$ Idem, ibidem, p. 7.

${ }^{71}$ Idem, ibidem, p. 8.

${ }^{72}$ Ver C., Toni. Um bom lugar: biografia oficial de Mauro Mateus dos Santos. São Paulo: LiteraRua, 2013. Segundo Gilmar Penteado, o rapper teve duas passagens pela polícia, em 1995: uma por porte de drogas e outra por tráfico. Ver Tiros atingiram orelha, boca e coluna. Penteado, Gilmar. Folha de S. Paulo, 25 jan. 2003.

73 "A favela chorou", op. cit. 
${ }^{74}$ Idem.

${ }^{75}$ Idem.

${ }^{76}$ POLLAK, Michael. Memória, esquecimento, silêncio, op . cit., p. 9.

77 Ver/ouvir "Mil faces de um homem leal". Racionais MC's. Direção: Daniel Grinspum. Brasil: Preta Portê Filmes, 2012, sobre Carlos Marighella, "protetor das multidões/ encarnações de célebres malandros/ de cérebros brilhantes/ [...]/ mártir, mito ou maldito sonhador/bandido da minha cor"; "Zumbi". Slim Rimografia. CD Amor, vida e música. São Paulo: 2006 (independente); "Revolução". Davi. Florianópolis: s./d. (independente), que reverencia a "guerrilha [que] está aí, ela nunca para/ como Luís Carlos Prestes, Rosa Luxemburgo e Che Guevara".

${ }^{78}$ Ouvir, por exemplo, "Resistência". NUC. Col. $1^{o}$ Encontro Nacional Nação Hip Hop Brasil, 2006, que rompe com alguns marcos consagrados, apontando que "Princesa Izabel, é uma farsa", e ainda defende que "agora a gente é que escreve a nossa história". Ouvir ainda "Nego negô". Inquérito, op. cit., que na mesma perspectiva destaca que "não foi bem do jeito que a história te ensinou/ Zumbi que lutou, a princesa só assinou".

${ }^{79}$ Ouvir, entre outras, “Devemos honra". Bandeira Negra. CD Transformação, op. cit.

80 "A favela chorou", op. cit.

${ }^{81}$ C., Toni, op. cit., p. 23.

82 Ver "Rap é compromisso". Sabotage. CD Rap é compromisso, op. cit.

${ }^{83}$ Ver "Respeito é pra quem tem". Sabotage. CD Rap é compromisso, op. cit.

${ }^{84}$ Wanderson Sabotinha. Brasil: Mó-H Filmes, s./d. 1 DVD (son., color.).

${ }^{85}$ Sabotage: o maestro do Canão. Direção: Ivan 13P. Brasil: 13 Produções, 2015. 1 DVD (son., color.).

${ }^{86}$ Sabotage propôs integração do samba ao rap. Pedro Alexandre Sanches. Folha de S. Paulo, 27 jan. 2003.

\section{Favela é Sabota}

Que sempre vai estar presente $[. . .]^{74}$

Na esteira dessas construções simbólicas janeiro de 2003 passou a ser um marco e Sabotage, um ícone cultuado de uma dada história de tempos recentes. Com sua capacidade de narrar e descrever por intermédio da música, Sandrão e seus amigos procedem a uma leitura de um processo social que, para uns tantos rappers, deve ser incorporada à história de um grupo social como a síntese de uma sensibilidade, de um estilo de vida, de um campo de expectativas e de tentativas de superação que são partilhados, acima de tudo, por gente da periferia. Essa função é explicitada em passagens como esta: "aqui alta cúpula é assim/ em sua memória/ DJ Hadje também está aqui/ suas pick-ups contam história". ${ }^{75}$

Essa música é expressamente um desdobramento da maneira como os rappers se relacionam com o passado e buscam produzir/inventar alguma história. Isso envolve um trabalho de enquadramento da memória, que "não pode ser construída arbitrariamente [...] deve satisfazer a certas exigências de justificação". ${ }^{76}$ No seu esforço de narrar "os outros 500" - retomando a figura de linguagem empregada por Nando, do ClãNordestino -, eles, geralmente, deram as costas para ícones/personagens históricos e se puseram a valorizar outros ${ }^{77}$, instituíram marcos históricos alternativos ${ }^{78}$, repensaram narrativas hegemônicas ${ }^{79} \mathrm{e}$, também, cuidaram de plasmar seus próprios referenciais e personagens exemplares. É por isso que Celo- $X$, tendo em mente Sabotage, recomenda a seus ouvintes: "aí, moleque, não se esquece/ guarde na mente eternamente" ${ }^{80}$

Catapultar Sabotage ao patamar de um símbolo da história contada e cantada nos raps foi uma obra coletiva, em grande parte alavancada pela morte prematura do artista que era filho de doméstica com catador de sucatas e que tinha um irmão deficiente mental e outro presidiário. Segundo seu biógrafo, Toni C., militante conhecido do movimento hip hop, "Mauro deixou de ser uma pessoa para se tornar um mito, uma entidade, uma marca [...] um estado de espírito que habita o coração e a cabeça das pessoas" ${ }^{81}$ Sua biografia, lançada em 2014, e o documentário Sabotage: o maestro do Canão, cuja première aconteceu em janeiro de 2015, integram um processo de formatação de sua imagem por muitos MCs nestes últimos anos.

Sabotage é presença relativamente constante na produção discursiva dos rappers, principalmente de 2003 em diante. Quando ele mesmo não é reverenciado, suas ideias são altamente valorizadas. Alguns de seus jargões são extraídos de músicas e falas em meios diversos e cultivados como axiomas que conteriam a síntese do espírito do rap. Exemplo disso é o uso que se faz das afirmações "o rap é compromisso" 82 e "respeito é pra quem tem". ${ }^{83}$ Reserva-se a ele, por essa via, um lugar especial na história do gênero, quando não da cultura brasileira. Não é por acaso que Andreas Kisser, do Sepultura, disse, em alto e bom som, que "o Sabotage [...] faz parte da cultura brasileira e ele tem que ser sempre lembrado" ${ }^{84}$, ou ainda que o cineasta Beto Brant acha que ele "é tipo um Bob Marley, Chico Science, [...] caras exemplares, assim... com uma obra muito forte".$^{85}$ Pedro Alexandre Sanches, por sua vez, reconheceu em Sabotage as qualidades que foram primeiramente identificadas pelos seus companheiros do hip hop: "postado na trincheira funda do rap, Sabotage era um desses mais talentosos artistas brasileiros jovens" ${ }^{86}$

As falas que erigiram uma aura de figura exemplar surgiram, em 
larga medida, sob a influência da morte do rapper. Quando Sabotage foi assassinado, ele era um artista com reconhecimento e em crescente destaque tanto na mídia quanto no mundo artístico. Seu primeiro disco contou com participações de vários dos principais nomes do rap no país à época, como Helião, Sandrão, Negra Li, Rappin Hood, Sombra, Bastardo, Black Alien. Além disso, ele tomou parte, emprestando suas rimas e sua voz, em discos de outros artistas e em outras produções artísticas e culturais, como os filmes Carandiru e $O$ invasor. Entretanto, como admitiu um de seus filhos, Sabotinha, "a fama dele aumentou mais depois que ele faleceu" ${ }^{87}$

E aumentou, insisto, devido ao investimento simbólico realizado por amigos e outros apreciadores de seu talento artístico. Depois de uma avalanche de comentários lançados ao público logo após sua morte (por meio de jornais, revistas e televisão), foram sobretudo os rappers que se encarregaram de cavar, com muito empenho, o lugar de Sabotage na memória e na história. Tal trabalho revela alguma relação com o que foi feito por gente que Pollak designou - sob inspiração de Gramsci - “historiadores orgânicos" ${ }^{\prime 88} \mathrm{E}$ isso foi tão bem-sucedido que o pessoal do Clãndestinos, tempos depois do falecimento do rapper, deixou no ar um questionamento que vaza certo grau de ceticismo/ironia sobre a imagem que se construiu de Sabotage: "todo mundo não gosta do cara?, não virou lenda?..." 89

A lenda começou a ser gestada em 2003 por mil e uma referências que se prendem a fatos da vida do rapper - seja como Sabotage, como Maurinho ou como Mauro Mateus dos Santos - e a reações de outras pessoas temperadas pelos sentimentos pessoais dos envolvidos. São vários os exemplos de como isso se deu. Em 2004, o personagem era lembrado pela turma do DMN, que classificou sua morte como uma "perda irreparável".$^{90}$ No ano seguinte, MV Bill tocou na mesma tecla. Para ele, Sabotage foi "a maior perda do rap até aqui". ${ }^{91}$ Os irmãos da 1 daSul também mencionaram a dor da perda, processando, no âmbito musical, elementos de seu trabalho de luto e contribuindo para gravar o nome do rapper na memória dos ouvintes do gênero. Cantaram: "Jorge Santista, Marquinhos, Sabotage/ Tudo eles pode/ furar e destruir/ mas a amizade, amizade de verdade/ ninguém mata assim". ${ }^{22}$

Mano Brown, a seu modo, ressaltou igualmente o tamanho da perda e o quanto o mano do Brooklin era fundamental para o rap brasileiro. No meio da sabatina a que se submeteu no programa Roda Viva, veio a questão:

José Nêumanne: Você nunca chorou, Mano?

Mano Brown: Não... lógico, já chorei.

Paulo Lima: Você lembra por quê? Você se lembra da última vez?

Mano Brown: Que eu chorei?... Quando o Sabotage morreu. Eu lembro que eu chorei. Chorei assim, bem discretamente, né? Tem uns irmãos que chorou muito mais. Mas eu chorei por dentro e cheguei a chorar também porque foi um dia muito triste pra nós, né? Um dia, assim... marcou muito. ${ }^{93}$

Muitas outras manifestações apareceram na mesma época para coroar uma imagem post-mortem para o rapper da zona sul. Thaíde foi outro nome de peso que contribuiu para o enquadramento da memória de Sabotage. Em 2007 ele declarou que "Sabotage, com o dom da rima, 100\% favela, indo pro cinema e fazendo mais sucesso [...] além de talentoso e inspirador, ele era também muito gente boa, sempre recebendo as pessoas com um

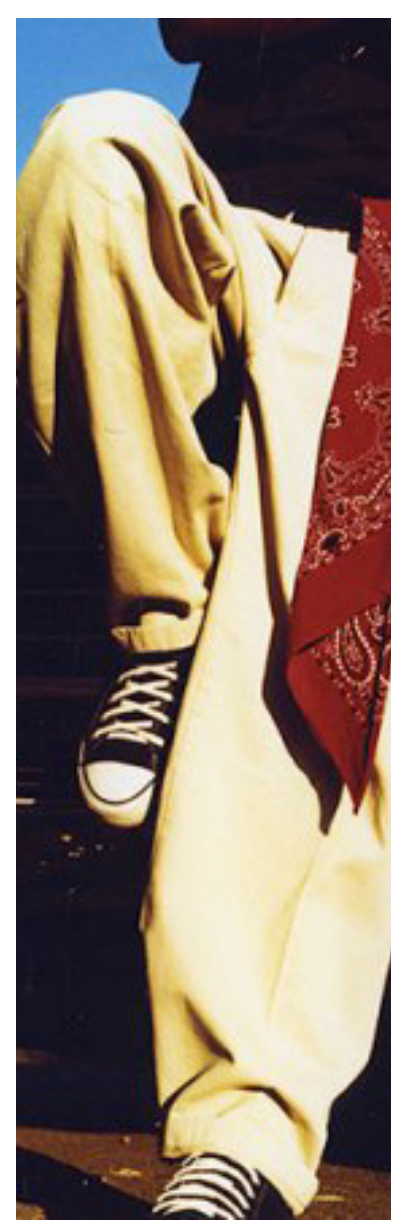

${ }^{87}$ Wanderson Sabotinha, op. cit.

${ }^{88}$ Que nas suas considerações "são os historiadores do Partido Comunista, os historiadores socialistas, os sindicalistas etc., cuja tarefa é precisamente enquadrar a memória". Ver POLLAK, Michael. Memória e identidade social. Estudos Históricos, v. 5, n. 10, Rio de Janeiro, 1992, p. 206.

${ }^{89}$ Entrevista com Clãndestinos. Hip Hop Alagoas, 21 nov. 2008.

${ }^{90}$ Entrevista com DMN. Rap Nacional, 26 fev. 2004.

${ }^{91}$ Entrevista com MV Bill. Rap Nacional, 24 jun. 2005.

92 "Final". Ferréz. Col. 1daSul: us que são representa. São Paulo: 1daSul, 2006.

${ }^{93}$ Mano Brown. Roda Viva. São Paulo: TV Cultura, 2006. 
${ }^{94}$ Entrevista com Rappin Hood. Enraizados, 2 maio 2007.

${ }^{95}$ Para Alexandre de Maio, "Sabotage é o Che Guevara da música. Ele revolucionou a vida dele, revolucionou o meio que ele vivia, levou a revolução dele pra outros lugares... morreu cedo, virou parte da história". Ver Sabotage: o maestro do Canão, op. cit.

${ }_{96}$ Para Sombra "o Sabota era um cara que era o seguinte: a gente... ele num tinha nem gravado o disco ainda e a gente já via ele como uma grande, como se fala... uma grande personalidade da trilha sonora do hip hop, que é o rap". Ver Sabotage nós. Direção: Guilherme Xavier Ribeiro. Brasil: Guarda Chuva/ MTV Brasil, 2013, 1 DVD (son. Color.).

${ }^{97}$ Os rappers do Z'África renderam suas homenagens a Sabotage em "Bom malandro". Z'África Brasil. CD Tem cor age. São Paulo: YB Music, 2006.

${ }^{98} \mathrm{O}$ DBS garante que "daqui a cem anos vão falar de Sabotage". Ouvir "Assim que é". DBS e A Quadrilha. CD O clã prossegue. São Paulo: Sky Blue, 2007.

${ }^{99}$ Criolo reconheceu que "eu sou nota cinco/ e sem provocá alarde/ nota dez é Dina Di, DJ Primo e Sabotage". "Sucrilhos". Criolo. CD Nó na orelha. São Paulo: Oloko Records, 2011.

${ }^{100}$ De acordo com o produtor Daniel Ganjaman, “o Sabotage [...] é um dos artistas mais geniais que o Brasil já teve e com certeza é um dos rappers mais criativos". Ver Sabotage: o maestro do Canão, op. cit.

${ }^{101}$ Emicida falou recentemente que "não só eu, nem meus camaradas, mas o hip hop inteiro entrou em uma grande depressão quando o Sabotage morreu. Porque imagina que o hip hop não é um gênero que tem artistas passando na televisão e tocando nas rádios, então quando você tem o maior nome... quando você perde o maior expoente da cultura, aí, irmão, o hip hop inteiro ficou sem chão [...] o hip hop voltou triste pra casa, o sonho acabou, sacou?" Ver Emicida. InteligenciaPontoCom. São Paulo, Centro Culural Fiesp Ruth Cardoso, nov. 2013.

${ }^{102}$ Sabotage nós, op. cit.

${ }^{103}$ Sabotage, o invasor. VAZ, Sérgio. O colecionador de pedras. São Paulo: Global, 2007. largo sorriso e dizendo 'cê é mó zica'. Quem teve o privilégio de conhecer pessoalmente o Sabota sabe disso e sabe acima de tudo a falta que ele faz pra gente e pra música, mas um dia a gente se encontra num bom lugar" ${ }^{94}$

Em perspectiva muito próxima, poderíamos contabilizar ainda as considerações feitas - em momentos e em circunstâncias bem diferentes - por Alexandre de Maio ${ }^{95}$, Sombra ${ }^{96}$, Z' África Brasil ${ }^{97}$, DBS ${ }^{98}$, Criolo ${ }^{99}$, Daniel Ganjaman ${ }^{100}$, Emicida ${ }^{101}$ e Tejo Damasceno, que lembra de haver dito a Zé Gonzales e Ganjaman, ali por 2000/2001, que “ele [Sabotage] é melhor que todo mundo" ${ }^{102} \mathrm{~A}$ imagem do rapper já estava mais ou menos estabelecida quando o poeta Sérgio Vaz publicou em um de seus livros a sua homenagem mais bem acabada ao maestro do Canão. Seus versos remetem, direta ou indiretamente, a outras operações discursivas a favor de Sabotage, sem deixar de apresentar elementos próprios. Sua contribuição é indispensável nesse empreendimento coletivo de pensar o MC, sua obra e o seu legado (cifrado em alguns versos do poeta que dialogam com os versos do maestro):

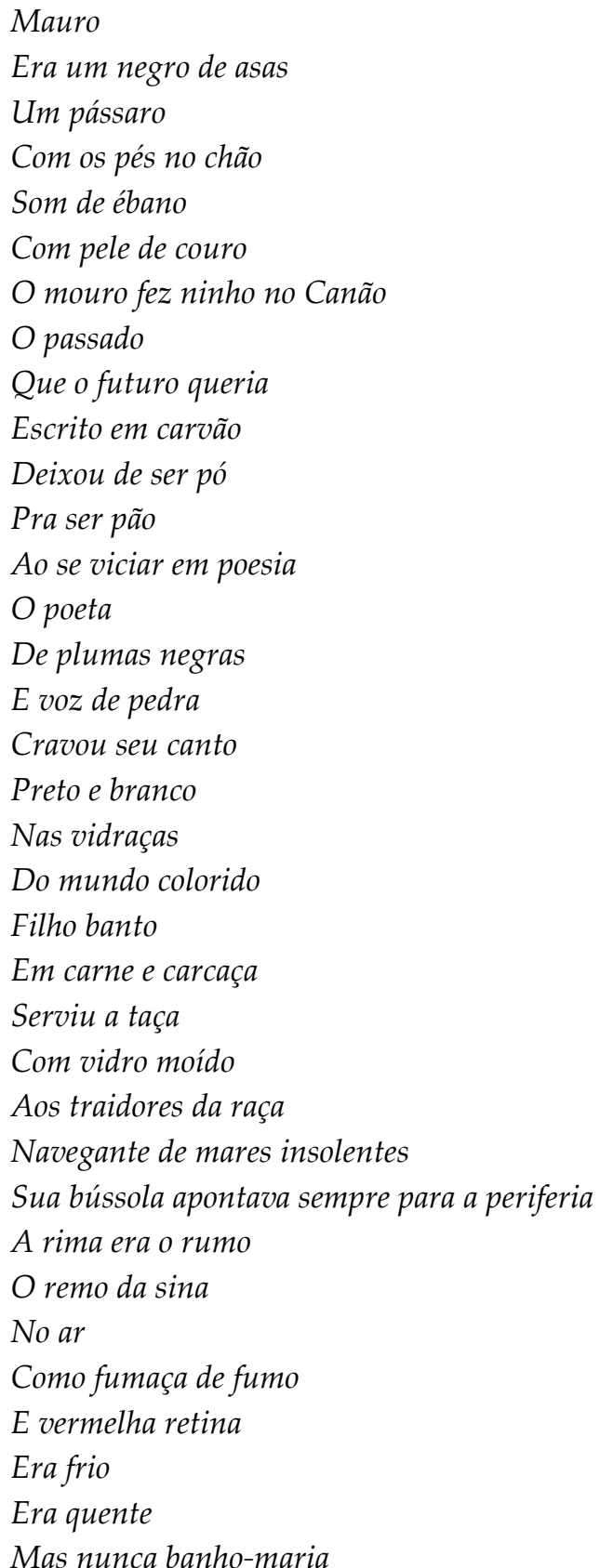

Mauro

Era um negro de asas

Um pássaro

Com os pés no chão

Som de ébano

ninho no Canão

O passado

Que o futuro queria

Escrito em carvão

Deixou de ser po

O poeta

De plumas negras

E voz de pedra

Cravou seu canto

Preto e branco

Nas vidraças

Do mundo colorido

e carcaça

Serviu a taça

Com vidro moído

Aos traidores da raça

Navegante de mares insolentes

Sua bússola apontava sempre para a periferia

A rima era o rumo

O remo da sina

No ar

Como fumaça de fumo

Evermelha retina

Era frio

Mas nunca banho-maria 
Um dia

Num voo curto

Depois de uma longa metragem

Um disparo sem rosto

Uma bala sem gosto

Calou o personagem

Diante disso

E sem nos esperar

Desfez o compromisso

Seguiu de viagem

E foi cantar em outro lugar

Num bom lugar ${ }^{103}$

As imagens e representações desse artista ou os sentidos e significados atribuídos à sua obra e/ou pessoa influenciaram na formulação de determinados valores do rap ${ }^{104}$, ajudaram a formar novos quadros do hip hop, estabeleceram um marco histórico próprio e um personagem histórico para ser lembrado e cultuado. $\mathrm{O}$ investimento dos rappers nesse passado imediato inclusive rendeu juros, à medida que a história de Sabotage continuou a ser contada e explorada ao longo dos anos. Tanto que o escritor Alessandro Buzo não deixou passar em branco os nove anos de sua morte ${ }^{105}$, data também lembrada por Projota, que postou em seu microblog no twitter que se "pode matar um homem, mas não sua ideologia". ${ }^{106}$

Os dez anos sem a presença física de Sabotage mereceram a atenção de rappers como Renan, do grupo Inquérito. Ele reposicionou a cruel história de Mauro, cuidando para que ela continuasse a se perpetuar e a contagiar novas pessoas:

Maestro do Canão, filho de Oxóssi
Morreu, ficou eterno aos vinte e nove
Deixou uma viúva e dois pivetes
Lembranças, saudades e muitos raps
Pixinguinha do Brooklin, ladrão rap resgatado
Preferiu trocar o 12 pela responsa dos palcos
Fez coisas surpreendentes e eu destaco duas delas
Misturou samba com rap e alegria com favela
Invasor da sul pro mundo, humilde até debaixo d'água
Atiraram no seu corpo mas nem relaram na alma
Apagaram nossa estrela como se fosse um incenso
Vida louca, cabulosa, o que vou fazer?
Lamento (ao som de Tim Maia)
Tá dentro do coração com amor e com carinho
Guardado num bom lugar, que Deus o tenha, Maurinho
“Um cara simples, gostava mais de ouvir e aprender
Até que..."107

E assim proseguem os rappers, construindo a história de Maurinho/ Sabotage ${ }^{108}$ ou do Brasil contemporâneo experimentado por eles. Vale, por fim, retomar o que declarou Douglas, do Realidade Cruel, a fim de contestar críticas feitas às narrativas do rap: "nós escrevemos a história, certo? De caneta, de lápis, com borracha e muitas vezes até com sangue". ${ }^{109}$ Não é à toa que Renan, em "Poucas palavras", manda "um salve a todos aqueles
104 O rapper Dexter, por exemplo, confessa que "quando paro para escrever uma letra lembro muito de uma frase do Sabotage: 'rap é compromisso, não é viagem'. Acredito que nossa maior afinidade seja essa." Apud C., Toni, op. cit., p. 246.

105 Na ocasião, Buzo escreveu: "9 anos de saudades da periferia/ 9 anos sem o Maurinho/ sem o poeta do Canão/ sem o mano sangue bom/ com seus cabelos pro ar/ sua rima veloz, furiosa/ na simpatia e humildade, muito longe chegou/ cinema, O invador, Carandiru/ deixou a todos exemplo/ o Rap resgata/ resgatou ele, Hood, RZO/ CD saiu, povo curtiu/ 'hoje choveu nas espraiadas, polícia sai do pé...'/ afirmou que o Canão era um bom lugar/ brilhou o Maurinho, virou Sabotage/ nunca é tarde.../ 9 anos sem seu caderno todo rabiscado,/ sem sua alegria de sobrevivente/ triste lembrar que não está mais com a gente/ mas sempre estará, em nossas mentes e corações/ seu recado eu escutei e vivo/ 'rap é compromisso, não é viagem'/ me incomoda um pouco, muita gente falando, estampando camiseta/rap é compromisso/e os poucos que dão atenção pro Wanderson e Tamires, filhos do Sabota/ até talento eles têm, os 'Sabotinha', mas têm também uma vida pela frente/ hoje, 9 anos sem Sabotage/ da periferia o sentimento é de saudade". BUZO, Alessandro. 9 anos sem Sabotage, 2012. Disponível em <buzo10.blogspot.com.br/2012/ /01/9anossemsabotage $>$. Acesso em 27 jan. 2016.

${ }^{106}$ Ver postagens de 24 jan. 2012 em www.twitter.com/projota.

${ }^{107}$ Respeito é pra quem tem. INQUÉRITO, Renan. Poucas palavras. Campinas: 2013 (independente).

${ }^{108}$ Karol Conka se engaja nessa causa em "Boa noite". Karol Conka. CD Batukfreak. São Paulo: 2013 (independente): "salve, Sabotage, MC de compromisso/ cumpre seu papel/ no céu/ que aqui a gente te mantém vivo".

109 Entrevista com Douglas. Outros 500, s./inf. 
que escreveram e continuam escrevendo a nossa história com legitimidade: Preto Góes, Gog, Sérgio Vaz e toda Cooperifa, Alessandro Buzo (Suburbano Convicto), Ferréz e 1daSul, Sacolinha, Elo da Corrente, Edições Toró, Jéssica Balbino, Alexandre de Maio, Rap Brasil, Vras 77, DJ TR, Toni C., Nelson Maca e tantos outros" ${ }^{110}$ Não por acaso, todos eles/elas mantêm alguma relação com o rap ou com o hip hop.

Artigo recebido e aprovado em fevereiro de 2018. 